\title{
Discursos éticos e
} estéticos: uma análise semiótica de editoriais fotográficos de marcas de fast fashion e slow fashion

Letícia Formoso Assunção

Doutoranda, Universidade Federal do Rio Grande do Sul / leticiafassuncao@gmail.com Orcid: 0000-0001-9595-4795 / lattes

Amalia Kusiak Martinez

Mestranda, Universidade Federal do Rio Grande do Sul / amaliakusiak@gmail.com

Orcid: 0000-0002-7186-7037 / lattes

Jocelise Jacques de Jacques

Doutora, Universidade Federal do Rio Grande do Sul / jocelise.jacques@ufrgs.br

Orcid: 0000-0003-2109-0677 / lattes

Enviado: 15/04/2020 // Aceito: 07/09/2020 


\title{
Discursos éticos e estéticos: uma análise semiótica de editoriais fotográficos de marcas de fast fashion e slow fashion
}

\begin{abstract}
RESUMO
Neste artigo, são analisados os valores simbólicos e as estratégias discursivas presentes em editoriais de moda produzidos por dois diferentes modelos de empresas de vestuário: uma marca de fast fashion e uma marca de slow fashion. Para tanto, é utilizado o aparato teórico-metodológico da semiótica discursiva desenvolvida por Algirdas Julien Greimas, tendo em vista o levantamento de hipóteses interpretativas e a apreensão dos efeitos de sentido vinculados às imagens fotográficas destes dois modelos de negócio. Como resultado, as leituras dos elementos visuais que compõem os editoriais analisados sugerem a promoção de valores distintos que apontam para as possíveis posições ideológicas discursivizadas pelas marcas.
\end{abstract}

Palavras-chave: moda. sustentabilidade. semiótica discursiva. 


\title{
Ethical and aesthetic discourses: a semiotic analysis of photo editorials of fast fashion and slow fashion brands
}

\begin{abstract}
In this article, the symbolic values and discursive strategies present in fashion editorials produced by two different models of clothing companies are analyzed: one fast fashion brand and one slow fashion brand. To this end, the theoreticalmethodological apparatus of discursive semiotics developed by Algirdas Julien Greimas is used, with a view to raising interpretive hypotheses and apprehending the effects of meaning linked to the photographic images of these two business models. As a result, the readings of the visual elements that are part of the analyzed editorials suggest the promotion of distinct values that point to the possible ideological positions discursivized by the brands.
\end{abstract}

Keywords: fashion. sustainability. discursive semiotics. 


\title{
Discursos éticos y estéticos: un análisis semiótico de editoriales fotográficos de marcas de fast fashion y slow fashion
}

\begin{abstract}
RESUMEN
En este artículo, se analizan los valores simbólicos y las estrategias discursivas presentes en los editoriales de moda producidos por dos modelos diferentes de compañías de ropa: uma marca de fast fashion y uma marca de slow. Para ello, se utiliza el aparato teórico-metodológico de semiótica discursiva desarrollado por Algirdas Julien Greimas, para plantear hipótesis interpretativas y comprender los efectos del significado ligado a las imágenes fotográficas de estos dos modelos de negocio. Como resultado, las lecturas de los elementos visuales que componen los editoriales analizados sugieren la promoción de valores distintos que apuntan a las posibles posiciones ideológicas discursivizadas por las marcas.
\end{abstract}

Palabras clave: moda. sostenibilidad. semiótica discursiva. 


\section{INTRODUÇÃO}

Enquanto um fenômeno cultural gerador de subjetividades, a moda soma desde a sua forma mais primitiva uma função significante, tornando-se a manifestação de um imaginário que auxilia na organização da vida coletiva. Ela é, com efeito, uma via de compreensão do social, a expressão das problemáticas ou qualidades de um tempo, que permite aos sujeitos integração a um universo de valores até então estabelecido. As roupas, na qualidade de articuladoras de significações, coincidem previamente com uma função fática da linguagem, pois, como expõe Barthes (2009), estabelecem comunicação antes mesmo da fala. A partir de percepções que antecedem qualquer diálogo, o vestuário enuncia mensagens com base em regras combinatórias e padrões de signos, os quais significam e constroem sentido conforme distintos valores, crenças e ideologias.

Objetos de expressão estética, de identificação e de diferenciação social, as roupas têm, como sugere Lurie (1997), uma gramática e um vocabulário equivalente àqueles da linguagem verbal. No entanto, diferentemente da linguagem verbal, a linguagem do vestuário é absolutamente permeável, tendo a sua relação significante-significado bem mais instável e temporária do que nos signos linguísticos. Isto porque a moda, entendida como um dos motores do sistema capitalista de produção e consumo, possui um caráter transitório, efêmero, fugaz. Em sua essência, segundo Lipovetsky (2009), está a aceitabilidade social e a sua natureza dinâmica, a qual tem adquirido cada vez mais velocidade, acelerando o tempo e produzindo excessos impulsionados pela ânsia do consumismo. 
Este feitio que a moda adquiriu com base na lógica da inconstância tem tornado a sua indústria uma das mais ambientalmente e socialmente insustentáveis. As condições questionáveis de produção das roupas, o trabalho em subcondições e os impactos ambientais gerados pelos processos e produtos, possuem grande amplitude e exigem um "preço alto a ser pago". É nesta medida que, como notam Manzini e Vezzoli (2008), as consequências do atual modelo de produção e consumo têm gerado uma urgência de criação de novos paradigmas e de um novo cenário para um desenvolvimento mais sustentável nos níveis econômico, social e ambiental.

Com base neste novo contexto, outras maneiras de pensar-fazer-consumir moda começam a surgir como referência na busca de soluções voltadas à sustentabilidade, com iniciativas de toda ordem. Mesmo havendo um distanciamento ontológico entre a indústria de moda convencional (liderada pelas fast-fashions) e os novos modelos de empresas que vêm valorizando iniciativas sustentáveis, percebe-se a capacidade de seus discursos servirem ambos como fonte e transferência de significados socioculturais. As marcas de moda, sejam elas com apelo sustentável ou não, necessitam buscar a regularização e consagração dos signos que se inscrevem nas suas peças de vestuário e nos demais componentes que integram os seus materiais publicitários.

Pensando no modo como estes discursos paralelos se apresentam, este artigo procura analisar as estratégias discursivas e valores simbólicos presentes em editoriais de moda produzidos por uma marca de fast fashion e uma marca de slow fashion. Nesta pesquisa, propõe-se refletir e caracterizar a estética das roupas e dos elementos que compõem plasticamente as fotografias de moda, tendo em 
vista a apreensão dos efeitos de sentido vinculados por estes modelos através das imagens. No entanto, cabe salientar que a análise das mensagens imagéticas, como refere Joly (1996, p. 44), "não consiste certamente em tentar encontrar ao máximo uma mensagem preexistente, mas em compreender o que essa mensagem, nessas circunstâncias, provoca de significações aqui e agora". Neste contexto, a apreensão dos efeitos de sentido pretendida ocorre por meio do levantamento de hipóteses interpretativas, as quais apontam os possíveis significados presentes nos textos visuais mediante relações entre diferentes instâncias do saber.

Para esta análise, será utilizado o aparato teóricometodológico da semiótica discursiva de matriz francesa desenvolvido pelo linguista Algirdas Julius Greimas, que tem como finalidade descrever os mecanismos de geração de sentido de qualquer linguagem figurativa ou plástica (GREIMAS; COURTÉS, 2008). O conteúdo veiculado pelos editoriais de moda eleitos para pesquisa é examinado levando-se em conta os três níveis de significação que compõem o plano do conteúdo: nível fundamental (em que se apreendem as oposições mínimas do sentido veiculado pelo texto), nível narrativo (onde os elementos opositivos do nível fundamental são transformados em objetos de valores) e nível discursivo (no qual o discurso é assumido por um sujeito a partir de marcas de pessoa, de tempo e de espaço). A fim de assumir-se um discurso analítico/interpretativo que vai além do conteúdo do texto, são trabalhados os formantes do plano da expressão (cromáticos, eidéticos e matéricos) que se constituem como recursos plásticos cujo efeito é tornar sensível um discurso sobre o mundo com base na relação com outros textos. 


\section{A SEMIÓTICA GREIMASIANA PARA LEITURA DE IMAGENS FOTOGRÁFICAS}

A semiótica discursiva, também conhecida como semiótica de linha francesa, semiótica da École de Paris ou semiótica gerativa, propõe-se como um método de investigação que se interessa pelo "parecer do sentido", o qual se apreende por meio das formas de linguagem que o manifestam. Esta ciência, que tem como principal expoente Algirdas Julien Greimas (1917-1992), linguista lituano radicado na França, possui o intuito de clarificar os processos de construção do sentido com base em postulados estruturais e na concepção da língua como instituição social. Enquanto disciplina e teoria do discurso com raízes fincadas nos estudos linguísticos, trabalha com práticas produzidas pela sociedade, contextualizadas histórica e socialmente.

No Dicionário de Semiótica, Greimas e Courtés (2008, p. 455) definem a semiótica discursiva como uma "teoria da significação", um método de investigação que se apropria do texto como um objeto de comunicação e que "sua primeira preocupação será, pois, explicitar, sob a forma de construção conceitual, as condições da apreensão e da produção do sentido". A semiótica é, assim, caracterizada como um aparato acessível para o estudo do objeto em foco, envolvendo diversos signos, linguagens, sinais e códigos. Para ela, interessam todos os signos verbais, não-verbais, seus modos de significação, de denotação, de conotação e de informação. O signo é o seu termo chave, sendo este, nas palavras de Santaella (2007, p. 8), "[...] qualquer coisa de qualquer espécie (uma palavra, um livro, uma biblioteca, um grito, uma pintura, um museu, uma pessoa, uma mancha de tinta, um vídeo etc.) que representa uma outra coisa". 
No intuito de reconhecer os mecanismos que engendram um texto, seus valores simbólicos e estratégias discursivas, trata-se na semiótica discursiva, primeiramente, apenas do seu plano de conteúdo, ou seja, do discurso veiculado que é estudado por meio de um percurso gerativo de sentido. Em um segundo momento se passa à análise do seu plano de expressão, isto é, dos elementos que constituem a materialidade do texto (visual, verbal, icônico, gestual, entre outros), suporte sensível do discurso. Na teoria greimasiana, a expressão suporta o conteúdo, configurando-se, desta forma, como duas etapas específicas, mas interdependentes.

Tomando como princípio o plano de conteúdo, analisamse três etapas ou níveis de significação que compõem o percurso gerativo de sentido, são eles: o nível fundamental, o nível narrativo e o nível discursivo (partindo dos elementos mais simples do discurso aos mais complexos e concretos). No nível fundamental apreendem-se as oposições semânticas mínimas veiculadas por meio do discurso, expressas por um valor positivo (eufórico) ou negativo (disfórico), que vão definir a linha argumentativa do texto. No nível narrativo são analisados os estados e as transformações dos sujeitos da narratividade em relação a um objeto de valor (Ov), o qual é descrito por Fiorin (2007, p. 04) como "o objeto desejável que faz o sujeito desejoso". No nível discursivo, por sua vez, o discurso é assumido por um sujeito em um tempo e um espaço e os elementos opositivos passam a ser, agora, revestidos mais concretamente por meio de figuras.

Ao final das análises do conteúdo de um texto, volta-se para as especificidades do plano de sua expressão. Neste momento, categorias relativas à cor (dimensão cromática), à forma (dimensão eidética), à materialidade (dimensão matéria) e à disposição no espaço (dimensão topológica) são trazidas às análises efetuadas, de modo a elucidar, de 
maneira mais precisa, a posição dos objetos como elementos de significação e de comunicação. Analisar os textos visuais por meio de tais categorias, segundo Castilho e Martins (2005, p. 80) "é assumir um discurso analítico/interpretativo que vai além do conteúdo que o texto apresenta, pois adentramos os domínios labirínticos de sua forma de expressão". Os traços destas categorias podem significar caminhos para leituras intertextuais, para apreensão de discursos ideológicos e para compreensão de momentos sociohistóricos.

Ao entender qualquer texto como um todo de significado, a semiótica discursiva torna-se um mecanismo útil para interpretação de fotografias de moda, pois convida o analista a perceber o que está expresso perante a imagem composta pela fusão de diversos elementos simbólicos. Estas percepções ocorrem por meio de relações entre as diferentes instâncias do saber, sendo, portanto, de natureza interdiscursiva, resultantes de fatores como conhecimentos, crenças, vivências e memórias. A função do analista, como sugere Joly (1996, p. 43), é precisamente "decifrar as significações que a 'naturalidade' aparente das mensagens visuais implica". Seguindo nos termos da autora, para uma interpretação plausível das imagens, deve-se procurar contemplá-las, examiná-las e compreendê-las, buscando, no lugar de receptor, apreender os efeitos de sentido que elas suscitam.

\section{MÉTODO}

A presente pesquisa, na busca por evidenciar as estratégias discursivas e os valores simbólicos com base na estética das roupas e dos elementos visuais que compõem as imagens fotográficas, tem como corpus de análise dois (02) editoriais de moda: um editorial de marca convencional de fast fashion e um de marca de slow fashion que valoriza 
iniciativas sustentáveis ${ }^{2}$. Como critério de seleção, para esta análise foram eleitas marcas de vestuário de abrangência nacional que disponibilizassem em plataformas on-line de domínio público editoriais de moda realizados em 2018³. Para a compreensão dos efeitos de sentido vinculados por estes diferentes modelos de negócio (fast fashion e slow fashion), optou-se pela análise do produto "editorial", pois, através do uso preponderante de imagens conjugadas, configura-se um espaço essencialmente visual em que se revela uma imagem e uma posição em relação a um público-alvo, e em que todos os elementos eleitos convergem na emissão de uma mensagem e de estilos propostos pelos autores, neste caso, as marcas de moda (RABAÇA E BARBOSA, 2002). Desta maneira, a análise de editoriais de moda nesta pesquisa permite uma (possível) compreensão dos discursos incorporados às narrativas dos dois modelos de empresas de moda, bem como a percepção das incidências temáticas, dos padrões estéticos e dos valores simbólicos divulgados.

Do ponto de vista teórico-metodológico, para este estudo servem de referência os fundamentos da semiótica discursiva sobre a construção de sentido. As significações veiculadas pelos editoriais de moda são trabalhadas nas instâncias constitutivas do plano de conteúdo e do plano de expressão, que tem seus conceitos embasados, sobretudo, nas obras de Greimas (1981, 2002, 2004) e Greimas; Courtés (2008). No plano de conteúdo é realizada a análise dos elementos do percurso gerativo de sentido (composto pelos níveis fundamental, narrativo e discursivo) que são relevantes para a compreensão do corpus do estudo. Já no plano de expressão a pesquisa é feita com base no exame dos elementos plásticos trabalhados nas categorias cromática, eidética e matérica ${ }^{4}$. A dimensão topológica não é abordada neste trabalho, uma vez que as imagens veiculadas pelos dois editoriais seguem a 
mesma lógica de distribuição planar, na qual o olhar é orientado a partir do foco central: a(s) modelo(s) fotográficas vestindo produtos de vestuário.

As imagens fotográficas são, nas análises aqui propostas, investigadas em sua totalidade, procurando-se observar os elementos de destaque que as compõem. Dentre alguns dos principais constructos examinados nas imagens aqui selecionadas, estão: o cenário; os elementos naturais; os objetos; a iluminação; a estrutura fotográfica; os aspectos físicos das modelos; e as principais características das peças de roupa e acessórios (como as suas cores, estampas, materiais e modelagens). No que se refere à estrutura analítica, em concordância com os postulados da semiótica greimasiana, as análises realizadas partem do plano de conteúdo rumo ao plano de expressão, pois é a partir do primeiro que (re)encontra-se sentido no segundo. A exploração destes dois planos e suas estruturas permite examinar 0 texto imagético como objeto de comunicação/significação.

\section{DAS ANÁLISES IMAGÉTICAS}

O primeiro editorial de moda a ser analisado (Figura 1) pertence a uma marca de fast-fashion e traz quatro fotografias das peças de roupas lançadas na coleção de primavera-verão de 2018/2019. O editorial é intitulado "De sol a sol" e, segundo a descrição da própria marca, as peças apresentadas são inspiradas nas cores e tramas da natureza. O conjunto de imagens possui uma narrativa linear, com um fio condutor temático que atravessa e confere unidade a todas as fotografias. Com um conceito que remete ao calor e à 
natureza, traz modelos, vestimentas, acessórios e cenários que dialogam com o tema proposto.

Figura 1. Editorial 01 de marca de moda de fast fashion

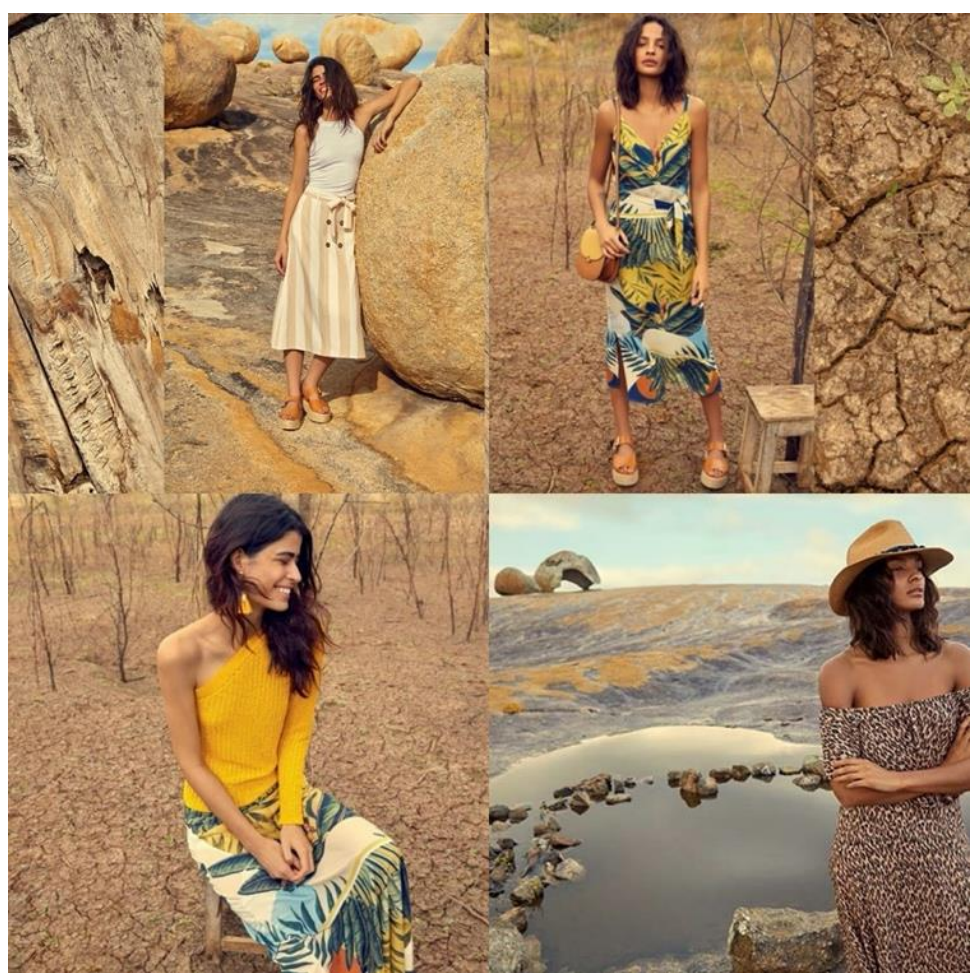

Fonte: montagem elaborada pelas autoras a partir de imagens disponibilizadas em canais públicos de comunicação on-line (2018).

A fim de exemplificar as particularidades do editorial 01 , propõem-se a análise pormenorizada das suas imagens. As fotografias que compõem o editorial têm como cenário um ambiente que se assemelha ao sertão, em uma zona de clima árido com temperaturas elevadas e precipitações escassas. Em relação aos elementos naturais que constituem a ambientação, vê-se pedras de grande porte, árvores secas e um pequeno lago com baixo nível d'água. Nas duas fotografias superiores que integram o editorial, a marca de moda realiza colagens digitais com imagens aproximadas de elementos da natureza, como um tronco de madeira seco e um solo rachado que, devido às estratégias de recorte e proximidade, 
salientam texturas que auxiliam na caracterização e conceituação do material fotográfico. É a luz natural que ilumina a locação. E o único objeto presente no editorial é um banquinho rústico de madeira que serve de apoio à modelo e à composição do ambiente.

As estruturações das fotografias são do tipo figura (as modelos em primeiro plano) e fundo (o recorte de paisagens áridas), criando um substrato visual de simples leitura e entendimento. No editorial, há a presença de diferentes modelos fotográficas, no entanto todas são mulheres com condições físicas similares, isto é, altas, magras, de pele parda, cabelos castanhos e ondulados. As produções de moda exibem saias, vestidos e blusas com uma cartela de cores variada, que vai desde tons neutros e terrosos, até pigmentos vibrantes como o amarelo, o verde e o azul. Algumas peças de roupas são lisas, enquanto outras possuem estampas que remetem à natureza ou listras com cores de pouco contraste. Em referência aos acessórios, pode-se observar a utilização de uma bolsa de material que remete ao couro em uma das imagens, bem como o uso de um chapéu com aspecto de palha trançada e de uma sandália de plataforma revestida de material com aparência de corda.

Dando início às análises, no que se refere ao plano de conteúdo do editorial 01 , é possível encontrar, no nível fundamental, as categorias da oposição semântica de base /cultura/ vs. /natureza/5. A /cultura/ é apreendida nas fotografias com valor eufórico, pois é atribuído um sentido positivo a ela, já que os elementos artificiais - roupas e acessórios - ganham destaque representando os valores almejados pela marca. No entanto, a /natureza/ é apresentada disforicamente, ou seja, de forma negativa, uma vez que o conceito expõe uma natureza seca, morta e inerte, indicando um sentido de perenidade. Nesta perspectiva, outra 
categoria que se agrega a esta primeira é /vida/ vs. /morte/, recebendo a /vida/ uma axiologização positiva equivalente à /cultura/, enquanto a /morte/ se torna negativa, assim como a /natureza/.

No nível narrativo deste editorial, percebe-se um programa narrativo de sedução e persuasão comuns à indústria da moda. As roupas e acessórios alinhados às últimas tendências tornam-se objetos de valor (Ov) positivo, com os quais o sujeito-destinatário consegue estabelecer uma relação de conjunção que pode ser relacionada aos termos eufóricos /cultura/ e /vida/. O manipulador criador - a marca de moda - constitui-se como um sujeito do "fazer", tendo como base um esquema narrativo canônico em que o destinador confere ao destinatário valores associados à aspectos culturais. Estes aspectos podem ser relacionados mais especificamente ao sistema fast-fashion que, nesta narrativa imagética, possui relações semânticas com o componente /vida/, ou seja, conota sentidos positivos, pois reflete a expressão de um tempo - o agora - que se define pelo transitório.

No nível discursivo, os temas e figuras explorados no editorial 01 evocam a oposição temática temporalidade vs. atemporalidade, em que o primeiro termo se relaciona à /cultura/ e à /vida/ e o segundo à /natureza/ e à /morte/. A temporalidade é percebida no discurso dos objetos - roupas e acessórios de moda - apresentados nas fotografias, os quais carregam um revestimento semântico aliado à sedução e à efemeridade que, assumindo as palavras de Lipovetsky (2009, p. 13), "tornaram-se os princípios organizadores da vida coletiva moderna". Já o tema atemporalidade é figurativizado pela natureza que, na condição de estar seca e morta, tende a não se modificar. 
Após a busca por elementos figurativos e semânticos presentes no plano de conteúdo, adentra-se os domínios relacionados às categorias plásticas por meio da análise do plano de expressão. No substrato visual das imagens do editorial 01 , primeiramente, observa-se as modelos vestindo produtos de moda, que são, em sua maioria, estampados em cores como verde, azul, rosa e amarelo, sendo esta última cor a que se sobressai na coleção. Posteriormente, têm-se o cenário revelando uma paisagem árida em tons terrosos, em que se destaca a cor marrom. Neste sentido, acentuam-se as relações opositivas entre CORES VIBRANTES vs. CORES NEUTRAS na dimensão cromática, que podem ser relacionadas simbolicamente à categoria no nível fundamental /cultura/ vs. /natureza/ e /vida/ vs. /morte/, bem como aos temas que Ihes são correlatos no nível discursivo. No que tange à dimensão matérica, as modelos fotográficas vestem peças com materiais e texturas que se opõem em significação: o chapéu e o solado da sandália são feitos de materiais com aspecto rústico, enquanto as roupas, sobretudo os vestidos e a saia estampada, trazem tecidos de aparência leve e fina. Desta forma, dispõe-se da categoria matérica SOFISTICADO vs. RÚSTICO, também associadas às categorias do nível fundamental /cultura/ vs. /natureza/ e seus correspondentes no patamar discursivo.

Realizadas a análise do editorial de uma marca de moda que trabalha com o sistema fast fashion, avança-se ao exame do discurso imagético da marca alinhada a uma proposta sustentável. O segundo editorial de moda a ser analisado (Figura 2) pertence a uma empresa que adota o padrão de produção slow fashion, tendo seus produtos realizados artesanalmente, fabricados com tecidos de refugo têxtil e tingidos de forma natural com corantes extraídos de frutas, verduras e folhas. O material fotográfico veiculado em um 
canal de comunicação no ano de 2018 não é nomeado e não possui descrição por parte da empresa. As imagens expostas neste material contam com um percurso de sentido linear, o qual é ordenado com base na organização e combinação dos seus formantes plásticos (cenário, cores, expressões, vestimentas etc.).

Figura 2. Editorial 02 de marca de moda de slow fashion

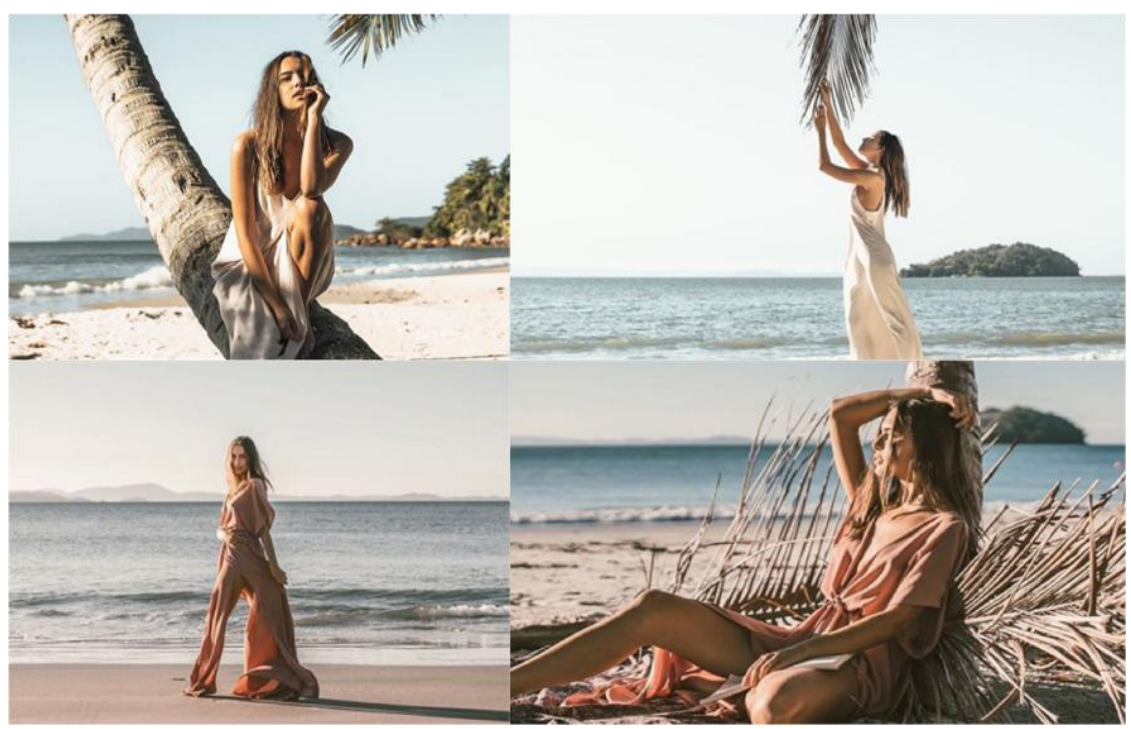

Fonte: montagem elaborada pelas autoras a partir de imagens disponibilizadas em canais públicos de comunicação on-line (2018).

As imagens pertencentes ao editorial 02 têm como cenário uma praia vazia de pessoas, a não ser pela presença de uma modelo, alta, magra, de pele branca e cabelos claros. No substrato visual, além desta mulher, vê-se uma espécie de palmeira e algumas folhagens secas caídas ao chão. Não há nenhum tipo de objeto ou elemento artificial, à exceção dos produtos de vestuário, os quais são todos lisos e possuem modelagem ampla (afastada do corpo), remetendo a sensações de leveza e conforto. Estas sensações são acentuadas com a não utilização de acessórios e com o efeito levemente esvoaçante dos cabelos soltos da modelo. Em relação à iluminação, a maneira como é revelada a incidência 
de luz natural sugere que as fotografias tenham sido realizadas em um final de tarde ou em um início de manhã. Os tons pastéis dominam as imagens, estando presentes tanto nas roupas, quanto nas nuances dos componentes naturais. Diferentemente do editorial analisado acima, neste a modelo interage com o ambiente, indicando uma relação afetiva com o lugar.

O discurso fotográfico do editorial 02 é estruturado na tentativa de conjugar os valores atribuídos aos elementos artificiais (roupas), com a semântica de um ambiente natural, figurativizado pela paisagem litorânea. Com apoio nestas relações, é possível estabelecer, tal como na análise realizadas anteriormente, o contato entre as noções de /cultura/ vs. /natureza/ na qualidade de universais semânticos do nível fundamental. No entanto, neste contexto, pode apreender-se que há uma conciliação entre os valores concebidos como contrários, ou seja, tanto o termo /cultura/ quanto o termo /natureza/ recebem axiologizações positivas, tornando-se eufóricos. Segundo Zilberberg (2004, p. 6), quando há presença de traços positivos nos termos de oposição, é gerado um "termo complexo", o qual relaciona os dois polos presentes na narrativa. Neste editorial, a integração à natureza parece ser um valor pretendido pela modelo nas fotografias e uma proposta realizada pela marca aos seus consumidores. Por meio de sedução e persuasão, entende-se que a empresa de vestuário pretende fazer o sujeito-destinatário entrar em conjunção com o objeto de valor (Ov) que, neste caso, é representado pela noção de sustentabilidade. Com base nesta leitura interpretativa, infere-se que este objeto se desmembra em um "fazer-ser", no sentido de um "fazer" relacionado à aquisição dos produtos de moda fabricados em um sistema slow fashion e um "ser" 
que se constrói como um sujeito identificado à natureza que dispõe de postura ética, crítica e consciente.

Neste editorial, a relação entre /cultura/ e /natureza/ pode ser verificada pelos termos opositivos leveza vs. força presentes no nível discursivo. No conjunto de imagens é possível observar a leveza como valor euforizado e relacionado à /cultura/ por meio das peças de vestuário com qualidades ligadas ao conforto, expressas na fabricação em tecidos delicados e em modelagens amplas. Já a força, que corresponde à /natureza/, sobretudo à figura da palmeira de tronco inclinado, é mais uma vez identificada euforicamente, por servir de apoio e como um elemento de interação com a modelo, concretizando a aproximação entre os termos. Neste sentido, o discurso do editorial 02 sugere um movimento de proximidade e integração à natureza através da produção de efeitos ideológicos observados na materialidade simbólica dos elementos que compõem as suas fotografias.

Em referência às categorias plásticas deste conjunto imagético, não é possível perceber, na dimensão cromática, relações opositivas entre as cores, uma vez que os elementos (naturais e artificiais) que constroem as composições fotográficas são em tons pastéis com alta luminosidade e pouca saturação. A não utilização de tons vibrantes ou estampas nas roupas corrobora a conciliação entre os valores apresentados no plano de conteúdo deste editorial, pois as colorações sutis se devem à forma de tingimento com pigmentos naturais utilizada pela marca. Ainda no interior do plano de expressão, na construção eidética salientam-se as formas das vestimentas, as quais são longas e soltas ao corpo. Estas apreensões se identificam com o termo LEVEZA encontrado no nível discursivo e se conjugam à ideia de conforto e bem-estar, remetendo às prováveis valorações positivas vislumbradas pela marca e seus consumidores. 
Efetuadas as análises imagéticas dos editoriais de moda sob o aparato da semiótica greimasiana, no item a seguir, buscando favorecer a compreensão dos valores simbólicos e das estratégias discursivas presentes nas fotografias, os dados aqui obtidos serão discutidos em maior profundidade.

\section{DISCUSSÃO E RESULTADOS}

Inicialmente, a partir de uma visão global das análises do plano de conteúdo, constata-se, nas avaliações do nível fundamental, uma recorrência dos termos opositivos /cultura/ vs. /natureza/. Do interior do percurso gerativo, foi possível depreender na análise do editorial da marca de moda de fast fashion (Figura 1) um movimento de euforização da /cultura/ e, por outro lado, de desforização da /natureza/. Estes termos assumem, nesta perspectiva, um distanciamento entre si, revelador da possível ideologia discursivizada pela marca. Nestas narrativas a natureza se faz visualmente presente pressupõe-se que pela necessidade atual da indústria convencional em envolver-se nas questões ambientais -, mas ainda não parece carregar valorações positivas que indiquem uma relação de pertencimento.

$\mathrm{Na}$ análise do editorial 01 , o objeto de valor (Ov) é figurativizado pelos produtos de moda, aos quais são atribuídas as qualidades promulgadas pela marca na busca pela conjunção com o sujeito-destinatário. Isto possivelmente ocorre com base em um ideal euforizado pelas empresas de fast fashion dentro de um movimento narrativo e discursivo de transitoriedade, a partir de uma estética programada, induzida através da reiteração semântica relacionada às tendências plásticas de moda do momento. Esta força da repetição, própria do sistema de produção e consumo pautados na efemeridade, é definida por Greimas (2002, p. 
81) como "simulacros passionais representáveis" engendrados dentro de uma estética da usura. Neste sentido, as estratégias de sedução e persuasão, ainda que tragam a natureza como pano de fundo, parecem buscar circunscrever os consumidores em um espaço de significação motivado preponderantemente pelo consumo.

No tocante aos aspectos plásticos e visuais da análise 01 , as cores e os materiais apresentados produzem efeitos de sentido que respondem aos anseios promulgados pelas fast fashions. Os produtos de moda fotografados obedecem a um estatuto semântico que se relaciona a uma ordem dinâmica e fugaz de aquisição. As cores vibrantes, os tecidos estampados e as características marcantes das peças, refletem o conceito de "moda rápida", desencadeador do desejo de possuir novas tendências em vista de assumir determinada moda, com base em uma necessidade plena de mudança. Os formantes plásticos dos produtos, que chegam a revelar oposições entre si (sofisticado vs. rústico) apontam para o hibridismo de estilos comum às marcas de moda convencionais (sobretudo às grandes empresas de varejo), por meio do qual os sujeitosconsumidores constroem suas identidades fundamentadas em identificações com certos códigos visuais e seus significados.

O editorial da marca de moda que valoriza iniciativas sustentáveis (Figura 2) também estabelece, no nível fundamental, relações entre os opostos semânticos /cultura/ vs. /natureza/. No entanto, neste material fotográfico, ambos os termos assumem significações positivas, promovendo a integração das suas representações simbólicas a partir de um termo complexo. Nas imagens interpretadas percebe-se a natureza recebendo uma posição de destaque e um efetivo envolvimento desta com as marcas. Esta abordagem supõe um modelo ideológico que reflete o modo de ser da empresa 
de moda em questão e do público que com elas se identificam segundo valores eufóricos.

Nas narrativas pertencentes à empresa de slow fashion, as peças de roupas não parecem ser as personagens principais, mas parte de um todo. Neste viés, a conjunção pretendida acontece com o objeto de valor (Ov) representado pela noção de sustentabilidade, que agrega valores éticos e estéticos relacionados ao meio ambiente. Segundo mecanismos semióticos, os sujeitos-consumidores parecem ser chamados a integrar este discurso de forma holística, assumindo "papéis sociais" definidos coletivamente em um modelo de conduta específico (GREIMAS, 1981, p. 130). Ainda que os produtos de vestuário apresentados na figura 02 sigam operando sob a lógica de consumo, estes papéis sociais são designados a partir de fatores de caráter simbólicos relacionados aos valores expressos pela "moda lenta".

No plano de expressão, por fim, os textos visuais veiculados pelo editorial 02 reiteram a orientação de um discurso sustentável, conforme os signos presentes na estética dos produtos de moda e dos elementos que compõem as fotografias. As dimensões cromática, matérica e eidética propõem leituras de traços significantes que apontam para características do consumo consciente. As peças de roupas monocromáticas e sem estampas, predominantemente em cores sutis ou neutras, se inserem no conceito de moda atemporal, não se enquadrando nas limitações propostas pelas tendências vendidas pelas fast fashions. À vista disso, a concepção estética dos produtos divulgados na imagem 02 abrange um estilo visual característico que, de certa forma, restringe os usos em um perfil de particular de consumidor. 


\section{CONSIDERAÇÕES FINAIS}

Neste artigo, procurou-se compreender os valores simbólicos e as estratégias discursivas presentes em editoriais de moda produzidos por uma marca de fast fashion e uma marca de slow fashion. Com o auxílio da semiótica discursiva, tornou-se possível o levantamento de hipóteses interpretativas que apontam para os efeitos de sentido veiculados por estes dois modelos de negócio analisados. Os resultados obtidos decorrem da apreensão de incidências temáticas, com base na observação e no cruzamento dos constructos visuais e elementos contextuais presentes no processo significativo e na constituição plástica das imagens fotográficas pesquisadas.

Com base em uma grande quantidade de signos presentes nos materiais publicitários da marca de fast fashion e da marca de slow fashion são expressas valorações distintas e estratégias discursivas que convocam os sujeitosconsumidores, se não a comprarem, ao menos a posicionarem-se ideologicamente. As fotografias estabelecem, desta forma, um espaço de diálogo em que relações sensíveis e inteligíveis se processam. Em todos os casos, cabe ressaltar que foi produzida uma análise/interpretação entre tantas possíveis. Os códigos abertos das imagens propiciam a compreensão e o reconhecimento de certos efeitos de sentido, porém sem fechar o seu movimento de significações.

\section{Notas de fim de texto}

1 A obsolescência pretende instigar no comprador o desejo de possuir algo mais novo, melhor e mais rápido que o necessário. Vance Packard (1965, p. 51) define a obsolescência programada como aquela relacionada à qualidade, ou seja, o produto é projetado 
para ser gasto em menor tempo que o normal. Já a obsolescência percebida se relaciona à desejabilidade de um produto que, em plenas condições, passa a ser considerado antiquado.

2 Os editoriais eleitos para esta pesquisa são compostos de diversas imagens fotográficas. No entanto, em razão da dimensão do artigo, o qual pretende ser um trabalho sucinto, optou-se pela seleção das quatro (04) imagens mais significativas e representativas de cada editorial, ou seja, as quatro imagens que possuem o maior número de elementos visuais e que são mais diversificadas entre si. Desta forma, neste artigo serão investigados dois (02) editoriais fotográficos compostos de quatro (04) imagens cada.

3 Faz-se necessário assinalar que um número reduzido de marcas de moda trabalha com publicidade no formato de editorial fotográfico divulgado em meio on-line. Considerando o critério de seleção desta análise - editoriais realizados em 2018 -, o número se torna ainda menor. Desta forma, o corpus desta análise foi selecionado tendo como base marcas de moda de expressividade nacional que atendessem ao requisito de temporalidade $e$ disponibilidade pública dos seus materiais publicitários.

${ }^{4}$ Cabe salientar que a disposição das diferentes categorias não representa uma hierarquização, já que são percebidas na relação que mantêm umas com as outras e não de modo isolado. Além disso, as categorias não aparecem com a mesma recorrência nas imagens dos editoriais de moda, podendo manifestar-se em uma e não nas demais, ou, pelo contrário, deixar de ocorrer em apenas uma delas.

4 Para permitir a distinção entre as diferentes categorias da análise, serão utilizados diferentes recursos tipográficos, são eles: letra normal entre barras para marcar as oposições semânticas de base do nível fundamental; aspas para indicar as competências de ação e transformação do nível narrativo; itálico para sinalizar as oposições temáticas do nível discursivo e letra maiúscula para as categorias do plano de expressão. Quando forem apresentados termos opositivos, estes serão relacionados por meio da abreviação "vs." referente ao vocábulo "versus".

\section{REFERÊNCIAS}

BARTHES, Roland. Sistema da Moda. São Paulo: Martins Fontes, 2009.

BERLIM, Lilyan. Moda e Sustentabilidade: uma reflexão necessária. São Paulo: Estação das Letras e Cores Editora, 2012.

CASTILHO, Kathia. Moda e linguagem. São Paulo: Anhembi Morumbi, 2006.

CASTILHO, Kathia; MARTINS, Marcelo M. Discursos da moda: semiótica, design, corpo. São Paulo: Anhembi Morumbi, 2005.

FIORIN, José Luiz. Paixões, afetos, emoções e sentimentos. Cadernos de Semiótica Aplicada, São Paulo, v. 5, n. 2, p. 2 - 15, 2007. 
FLETCHER, Kate; GROSE, Lynda. Moda \& Sustentabilidade: design para mudança. São Paulo: Editora Senac São Paulo, 2011.

GREIMAS, Algirdas Julien. Semiótica e Ciências Sociais. São Paulo: Cultrix, 1981.

GREIMAS. Da imperfeição. São Paulo: Hacker, 2002.

GREIMAS. Semiótica figurativa e semiótica plástica. In: OLIVEIRA, Ana Cláudia de (org.). Semiótica plástica. São Paulo: Hacker Editores, 2004. p. 75-96.

GREIMAS, Algirdas Julien; COURTÉS, Joseph. Dicionário de semiótica. São Paulo: Contexto, 2008.

JOLY, Martine. Introdução à análise da imagem. São Paulo: Papirus, 1996.

LIPOVETSKY, Gilles. O Império do Efêmero: a moda e seu destino nas sociedades modernas. São Paulo: Companhia das Letras, 2009.

LURIE, Alison. A linguagem das roupas. Rio de Janeiro: Rocco, 1997.

MANZINI, EZio; VEZZOLI, Carlo. O desenvolvimento de produtos sustentáveis: os requisitos ambientais dos produtos industriais. São Paulo: EDUSP, 2008.

PACKARD, Vance. Estratégia do desperdício. São Paulo: Ibrasa, 1965.

RABACA, Carlos Alberto; BARBOSA, Gustavo Guimarães. Dicionário de comunicação. São Paulo: Campus, 2002.

SANTAELLA, Lúcia. Linguagens líquidas na era da mobilidade. São Paulo: Paulus, 2007.

WEEKS, Jeffrey. O corpo e a sexualidade. In: LOURO, Guacira Lopes. (Org.). O corpo educado: pedagogias da sexualidade. Belo Horizonte: Autentica, 2000.

ZILBERBERG, Claude. As condições semióticas da mestiçagem. In: CANIZAL, E. P.; Caetano, K. E. (Orgs.). O olhar à deriva: mídia, significação e cultura. São Paulo: Annablume, 2004. 